This item was submitted to Loughborough's Research Repository by the author.

Items in Figshare are protected by copyright, with all rights reserved, unless otherwise indicated.

\title{
Introduction: the poverty of policy? Gaps in anti-poverty policy for children
} and young people

\section{PLEASE CITE THE PUBLISHED VERSION}

http://dx.doi.org/10.1017/S1474746408004430

\section{PUBLISHER}

(c) Cambridge University Press

VERSION

VoR (Version of Record)

\section{LICENCE}

CC BY-NC-ND 4.0

\section{REPOSITORY RECORD}

Predelli, Line Nyhagen, Alan France, and Chris Dearden. 2019. "Introduction: The Poverty of Policy? Gaps in Anti-poverty Policy for Children and Young People”. figshare. https://hdl.handle.net/2134/7247. 
This item was submitted to Loughborough's Institutional Repository (https://dspace.lboro.ac.uk/) by the author and is made available under the following Creative Commons Licence conditions.

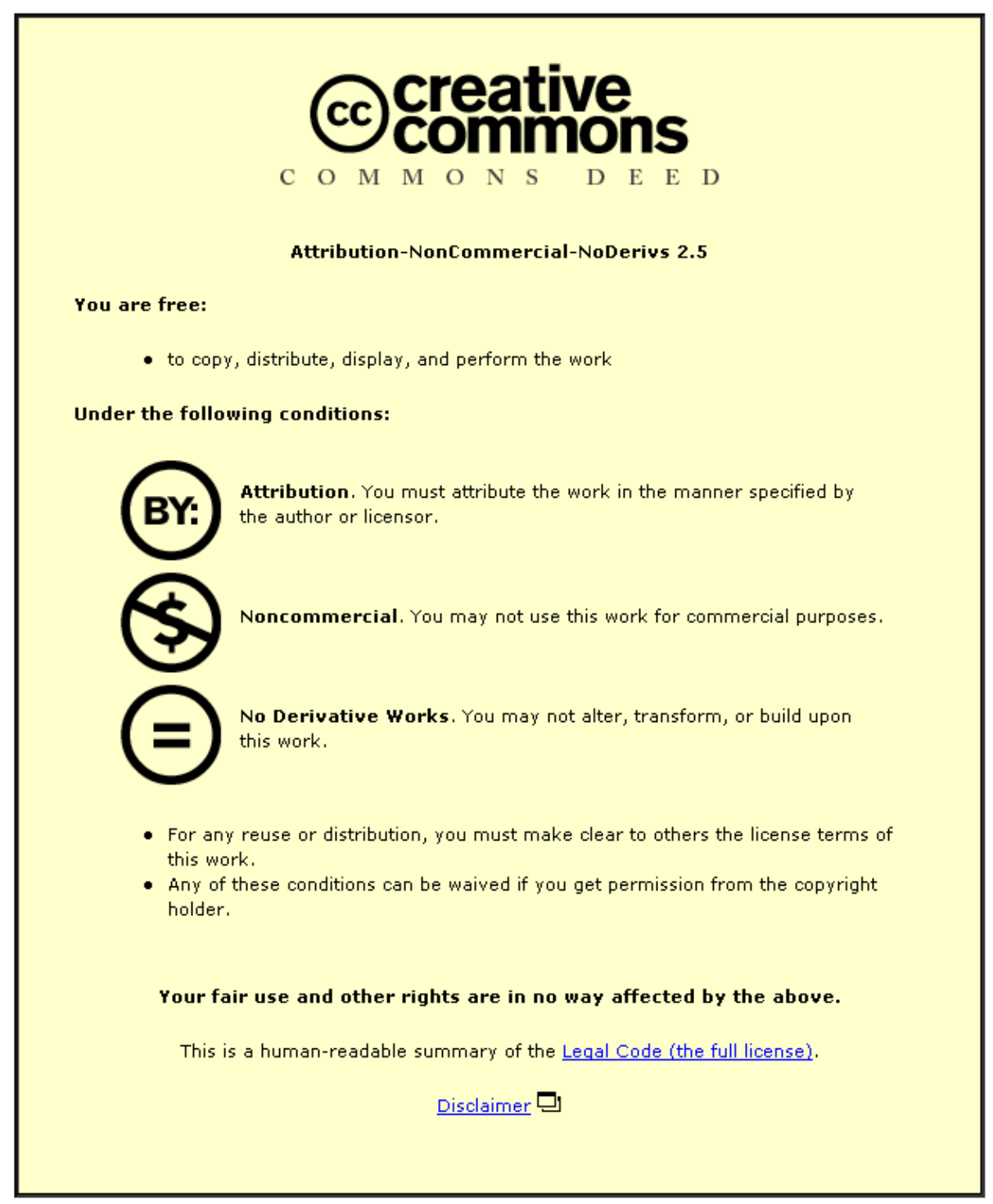

For the full text of this licence, please go to: http://creativecommons.org/licenses/by-nc-nd/2.5/ 


\title{
Introduction: The Poverty of Policy? Gaps in Anti-Poverty Policy for Children and Young People
}

\author{
Guest editors: Line Nyhagen Predelli*, Alan France ${ }^{* *}$ and \\ Chris Dearden
}

Centre for Research in Social Policy, Department of Social Sciences Loughborough University

E-mail: *L.N.Predelli@Iboro.ac.uk, **A.P.France@Iboro.ac.uk, ${ }^{* * *}$ C.M.Dearden1@lboro.ac.uk

The focus of this themed section is on identifying gaps in anti-poverty policy towards children and young people. The idea to address this question originated at the conference 'A Fairer Society? A Review of Policies for Vulnerable Groups' organised by the Centre for Research in Social Policy (CRSP) at Loughborough University in September 2006. The section offers a combination of papers from the conference (Bradshaw and Richardson; Smith; Sutton) and papers commissioned specifically to deal with gaps in anti-poverty policy towards children and young people (Lloyd; France; Phung). An overview of some useful sources has also been included (Davis and Sandu).

Despite major policy initiatives in this area since New Labour came to power in 1997, child poverty levels are still unacceptably high. In 2005, the UK scored close to bottom (20th place out of 26) in the child poverty league among the world's richest countries (UNICEF, 2005). In actual numbers, between 2.9 and 3.9 million children in the UK today are measured as poor, with the two figures presenting the number of poor children before and after housing costs are considered, respectively (HBAI, June, 2008). ${ }^{1}$

In 1999, Prime Minister Tony Blair famously declared that 'our historic aim [is] that ours is the first generation to end child poverty forever' (Blair, 1999: 7). In order to fulfil this ambitious aim, the Government set itself interim targets of reducing child poverty by one-quarter by 2005, halving it by 2010 and eventually eradicating child poverty by 2020 . Despite having positively lifted 600,000 children out of relative poverty since 1998-99, ${ }^{2}$ the Government missed its first interim target. It is also likely to miss the second interim target, and only major public investments will secure realisation of the ultimate goal of ending child poverty by 2020 (Work and Pensions Committee, 2008; Freud, 2007; Harker, 2006; Hirsch, 2006). Importantly, those that have been moved out of poverty so far are the easiest to help, while the poorest children, those in severe poverty, 'have been left behind' (Magadi and Middleton, 2005). Lifting more children out of poverty will demand increased political efforts and more generous public expenditure year on year. Estimates of the amount of new public money required to meet the halfway target in 2010 hover around $£ 4$ billion (Brewer et al., 2006; see also Hirsch, 2006) to be invested in child benefits and child tax credits. In the 2008 budget, the Government met a part of this need by committing itself to spending just below $£ 1$ billion on policy measures such as disregarding Child Benefit in calculating income for Housing and Council Tax benefit, increasing the Child Benefit for the first child to $£ 20$ per week, and increasing the child element of the Child Tax Credit. Ending child poverty by 2020 (or in effect reducing it to an 'acceptable level', comparable with that of Scandinavian countries) is projected to cost more than $£ 30$ billion (Brewer et al., 2006; Hirsch, 2006). 
How to measure poverty remains a much debated and contested issue, which is dealt with both directly and indirectly by the authors in our themed section. The proxy measure mostly used by Government to assess whether someone is living in poverty, and the measure to which Government targets are attached, is a relative income measure determining poor children to be those 'living in households below 60 per cent of contemporary median equivalised household income' (HM Treasury, 2008: 5). Crucially, we do not really know whether the ' 60 per cent of median income' provides an adequate standard of living, nor do we fully understand what things poor children are deprived of or go without compared to their non-poor peers (Adelman et al., 2003: 16). Relying exclusively on income level as a proxy measure for poverty has implications for policy and creates gaps in anti-poverty policy for children and young people. In focusing on adults, the income poverty approach also ignores the perspectives of children and young people, and the quality of life and well-being they actually experience in their daily lives.

In recent years, both researchers and the government (DWP, 2003) have moved beyond the limited approach of relative poverty measured by income level. Other measures of material deprivation, including going without certain items and activities that are deemed basic and necessary, in combination with social and emotional indicators of child well-being, have been developed in order to provide a more comprehensive view of what it means for children to be poor (Adelman et al., 2003; Magadi and Middleton, 2005; UNICEF, 2007). In 2007, the Report Card on 'Child well-being in rich countries' was published by UNICEF, offering a multidimensional picture of child well-being measured by 'material well-being, health and safety, education, family and peer relationships, subjective well-being, and behaviours and lifestyles' (ibid.). Among the researchers behind the landmark UNICEF report were Jonathan Bradshaw and Dominic Richardson, who in this themed section continue to offer an international perspective on child income poverty and child well-being, thus usefully situating the UK in a broader context. Building on previous work, Bradshaw and Richardson consider child well-being in three different contexts: the OECD (Organisation for Economic Cooperation and Development), the EU (European Union) and CEE/CIS (Central and Eastern Europe and the Commonwealth of Independent States). They find that for OECD countries, income poverty is still a good indicator of child well-being, but this is not the case for EU and for CEE/CIS countries. They argue that, in order to better understand children's well-being, it is necessary to look beyond income measures of poverty and to include life satisfaction, health and safety, and opportunities for play and recreation, as well as teenage pregnancy rates, among the well-being measures. Income measures of poverty are of course still important (see Strelitz and Lister, 2008), but by developing multi-dimensional perspectives on poverty some of the gaps in anti-poverty policies for children and young people can be addressedin particular aspects (other than income) that are associated with well-being.

Liz Sutton also draws on the theme of child well-being in her analysis of how children from different social backgrounds use public space to play, and the importance of street play for disadvantaged children. While the street is often the only space available for disadvantaged children to play, the street can also be a risky place for them in terms of health and safety. The issue of children's play has recently moved up on the Government's policy agenda, but much is still to be done in safeguarding enough open public spaces for children's play, and especially for disadvantaged children who have limited access to organised activities. Sutton offers a unique perspective on children's play, as her research is based on a participatory study where children from both an affluent and a disadvantaged 
area were invited to offer their own perspectives on what is important to them. The children were directly involved in decisions concerning research methods and data collection, and in interpreting research findings. Echoing the good practice in which Sutton engaged as a researcher, the leading national charity The Children's Society launched its 'Good Childhood Inquiry' in 2006 by inviting children and young people to talk about what they think constitutes the basic elements of a good childhood. The Government has also engaged children and young people in its follow-up consultations to the Every Child Matters Green Paper from 2003. Such participatory practices are inspirational to all those who investigate the lives of children and make decisions that affect them. They imply that children's rights and perspectives, rather than being marginalised from debates on poverty and well-being, have to continually move to the centre of policy attention.

Half of all children measured as living in poverty live in households that are in work, while half live in households that are out of work. The main strategies chosen by the Government to tackle child poverty include increasing employment rates, introducing tax credits and making sure that the adult rate of the minimum wage, in combination with working and child tax credits and child benefits, provide a better income for families (DWP, 2004). While the 'welfare-to-work agenda' has benefited both individuals and families in terms of raising skill levels and increasing in-work experience and income, it remains an insufficient, and indeed sometimes counter-productive (for example for parents caring for disabled children) strategy towards lifting children and families out of poverty. Indeed, national and international research points to the limitations of liberal welfare regimes such as the UK (Esping-Andersen, 1990, 1999) in significantly reducing or eliminating child poverty. UK Government policy emphasises means-tested rather than universal benefits, and actual benefit levels fall well below the poverty level set by Government itself. In other words, living on benefits provides an income that falls way below 60 per cent of median income, which is the standard proxy measure used for poverty (see Sharma, 2007). One of the key policy gaps that still needs to be addressed by government is the adequacy of benefits, and in particular adult benefits (Work and Pensions Committee, 2008). Unless benefit levels are uprated to a higher level, the UK's child poverty level is likely to increase within the next 20 years (Sutherland et al., 2008). While benefits such as Income Support and Job Seekers Allowance, Working and Child Tax Credits, and Minimum Wage levels are necessary to tackle poverty, these policies remain insufficient in order to significantly reduce the poverty and social exclusion experienced by families and children.

Unsurprisingly, higher government spending to tackle poverty is associated with lower child poverty rates (UNICEF, 2005). Universal and preventative approaches, in combination with targeted approaches to reach the most severe cases, are generally perceived by international experts as the best route to combat child poverty and social exclusion (Frazer and Marlier, 2007). Countries with the lowest child poverty rates are, following Esping-Andersen's terminology, 'social democratic' welfare regimes that emphasise universal benefits, higher benefit levels and government subsidy and equalisation of private and public childcare arrangements. Affordable and good quality childcare is generally viewed as both a means to move parents into work and to provide children with social and educational skills that are the basis for life-long learning. New Labour's national childcare and family support strategies have, as Eva Lloyd demonstrates in her article, particularly focused on improving mothers' labour market participation and children's future educational achievements. As Lloyd argues, these strategies have 
reflected a clear anti-poverty focus, but the rights of children themselves, and their quality of life and well-being, have not been central to New Labour's discourse on childcare. Moreover, gaps in current policies mean that the needs of large families, families with a disabled child or parent and ethnic minority families are largely unmet. In the UK, the delivery of childcare and family support has mainly been implemented within a mixed economy of welfare, and Lloyd explores whether this mixed market economy promotes separate markets for the poor and the better off, while hindering the achievement of child poverty strategy outcomes. Lloyd concludes that poor children would actually be best served by 'a universal, publicly funded and equitable system of early childhood education and care provision uncoupled from parental employment status' (Lloyd, this volume). In policy terms, this could mean expanding the universal education entitlement for children below compulsory school age from the current limited entitlement of 12.5 hours per week in term time only for children three and four years of age. Furthermore, the requirement for parents to work a minimum of 16 hours to qualify for childcare tax credits could be abandoned in favour of a system in which such credits were linked to the individual child, where children are viewed as social actors in their own right.

Research evidence shows that the target of abolishing childhood poverty cannot be met simply by a continuation of current policies. In particular, there are groups of children who are especially at risk of poverty and who merit further policy attention. These include children in families in transition (between work and no work, and from couple to lone parent families), black and ethnic minority children, disabled children and those with disabled parents, children in larger families, and young people leaving care. Gaps in anti-poverty policy for these groups are addressed in different ways by the authors in our themed section. Noel Smith demonstrates the importance of a dynamics perspective on poverty that recognises that families and their children move in and out of poverty. Estimates of the UK child poverty rate is based on a snapshot of the number of children in relative income poverty at a single point in time, which in effect disregards changes in poverty over time. Strategies and policies based on the single point in time estimate overlook the impact of poverty dynamics or factors that move children and families in and out of poverty. As children and families moving in and out of poverty are difficult to target, only adequate levels of income over a sustained period of time can provide the necessary protection of children from recurrent poverty. Children in persistent and severe poverty (unbroken periods of low income over four years or more) are among the most difficult to lift out of poverty (Adelman et al., 2003; Magadi and Middleton, 2005). They include children 'in households where adults move between work and benefits, where there are children under 10 years, where there are more children (especially three or more) in the family and those who move from couple to independent families' (Magadi and Middleton, 2005: xviii). If these children's needs remain unmet, the Government's ambitious aim of eradicating child poverty by 2020 will not be fulfilled. In terms of policy gaps, Smith points to the need for an increasingly responsive benefit system that can 'smooth' the income of families when parents move in and out of work. Households with low incomes might also benefit from tailored training and education, affordable and flexible childcare and personalised services. For workless households, however, the welfare-to-work agenda proves insufficient, as children in families with parents unable to work are being left out by design from potential improvements in income status produced by in-work participation. Those who cannot work must be provided for at an adequate level. 
The gaps in anti-poverty policy identified above and by the contributors to this themed section apply strongly to ethnic minority groups that are among the most disadvantaged in the UK. Child poverty rates among ethnic minorities are generally higher than among the white majority, and they are particularly high among the Caribbean, Pakistani and Bangladeshi groups. As Viet-Hai Phung demonstrates in his review of recent research literature, much of the ethnic difference in child poverty rates can be explained by differences in employment, unemployment and pay rates between the ethnic majority and minority groups. Disadvantage is also exacerbated by racism and discrimination, large family size, ill-health, occupational segregation, low take-up of benefits and tax credits, low female employment and industrial decline. Specific policy strategies are likely to benefit ethic minority groups. While increased lone parent employment is likely to benefit Black Caribbeans, improved employment rates among couple households is likely to benefit South Asian families. Again, affordable and flexible childcare is key to moving ethnic minority children and families out of poverty. Specific proposals to increase take-up of childcare among ethnic minority groups include the extension of Working Tax Credit to all children in a family (currently it covers only up to two children) and a substantial increase in the universal entitlement to free childcare.

A Government focus on meeting statistical targets implies that those who do not appear in statistical returns can easily be overlooked. Such 'invisible' groups, despite being among the poorest of all, have mainly been neglected by government policy (Preston, 2005). They include children of asylum seekers, refugee children, homeless adults and children, and travellers. In our themed section, Alan France addresses problems faced particularly by vulnerable young people as they navigate their way towards independent adulthood. The Government's child poverty strategy is mainly focused on children in families aged 0-15, while poverty among young people aged 16-25 has received limited attention. Transitions to adulthood and poverty in relation to such transitions are also overlooked in government policies seeking to tackle social exclusion. France argues that the problem of youth poverty has indeed been marginalised, and that challenges in relation to youth incomes and adequate housing support for young people must be addressed. Furthermore, the welfare to work agenda also faces limitations in relation to youth. The proportion of young NEETs (not in education, employment, or training), which is currently at about 10 per cent, suggests that many youth fall outside the government's prescribed options of staying on at school or getting a job. Young people who do work are often hit hard by the government's arbitrary decision that young people can get by on less income than other people, in so far as the minimum wage is age banded (from October 2008 , the minimum hourly rate for adults 22 and over is $£ 5.73$, while it is $£ 4.77$ for adults aged 18-21, and $£ 3.53$ for young people aged 16 and 17). In terms of policy to reduce poverty among young people, raising the minimum wage for the young by abandoning the age banding would be a significant step forward. Furthermore, removing the age banding of benefits like the Job Seekers Allowance and providing adequate benefit levels would support young people's transitions to independent adulthood. ${ }^{3}$ Providing adequate housing support for young people, including opportunities for independent living for young mothers, would signal that young people are to be treated as individuals in their own right and not as dependent on their families.

As editors it is our hope that the themed section succeeds in addressing some of the current gaps in anti-poverty policy for children and young people, and in identifying policy strategies that can be used to further reduce the poverty experienced by so many children 
and young people in the UK. In order to target policies more effectively, there needs to be a continued focus on improving how child poverty is measured, taking into account the rights and perspectives of children themselves, and applying a multidimensional perspective on children's well-being. The government urgently needs to address the issue of providing for children in workless families, as well as for those in working families. Accessible and affordable childcare for all children, independent of the job status of their parents and carers, is central to securing the best prospects for children and young people. Recognising the importance of difference and diversity based on gender, ethnicity, disability or geography implies that policies must be developed further to address current inequalities and injustice. The dynamics of poverty demands that policy attention is focused on both those that move in and out of poverty, and on those that experience persistent and severe poverty. Politicians must face up to the challenge of convincing both decision-makers and the general public that the elimination of poverty is crucial to securing a just society where all children and young people are given the chance to live a good life.

\section{Acknowledgments}

As Guest Editors we are grateful to all the anonymous referees for their valuable comments and suggestions. We also wish to thank Nicola Selby for her administrative support.

\section{Notes}

1 The figures are for 2006/07, with the lowest estimate being the number of children living in families with below 60 per cent of median income before housing costs, and the highest estimate being the number of children living in families with below 60 per cent of median income after housing costs.

2 Using the before housing costs measure referred to in footnote 2.

3 In April 2008 JSA rates for 16-18 year olds were aligned with 18-24 year olds which is a positive move in the right direction although it is important to recognise for 16-18 year olds these payments remain discretionary, around hardship, and that benefit rate differences still exist between 16-24 year olds and the rest of the adult population.

\section{References}

Adelman, L., Middleton, S. and Ashworth, K. (2003), Britain's Poorest Children: Severe and Persistent Poverty and Social Exclusion, London: Save the Children.

Blair, T. (1999), 'Beveridge revisited: a welfare state for the 21st century', in R. Walker (ed.), Ending Child Poverty, Bristol: The Policy Press, pp. 7-18.

Brewer, M., Browne, J. and Sutherland, H. (2006), Microsimulating Child Poverty in 2010 and 2020, York: The Joseph Rowntree Foundation.

DWP (2003), Measuring Child Poverty, Department for Work and Pensions.

DWP (2004), Report on Child Poverty in the UK, Norwich: Department for Work and Pensions and TSO, The Stationary Office.

Esping-Andersen, G. (1990), The Three Worlds of Welfare Capitalism, Cambridge: Polity Press.

Esping-Andersen, G. (1999), Social Foundations of Postindustrial Economies, Oxford: Oxford University Press.

Every Child Matters, Green Paper, Cm 5860, September 2003. 
Frazer, H. and Marlier, E. (2007), Tackling Child Poverty and Promoting the Social Inclusion of Children in the EU: Key lessons, The European Commission.

Freud, D. (2007), Reducing Dependency, Increasing Opportunity: Options for the Future of Welfare-toWork, Leeds: Corporate Document Services.

Harker, L. (2006), Delivering on Child Poverty: What Would It Take? Norwich: The Stationery Office.

HBAI (June 2008), 'Households below average income (HBAl) 1994/95-2006/07', http://www.dwp.gov. uk/asd/hbai/hbai2007/contents.asp

HM Treasury (2008), 'Ending child poverty: everybody's business', Office of Public Sector Information, Norwich, www.hm-treasury.gov.uk.

Hirsch, D. (2006), What Will It Take to End Child Poverty? Firing on all Cylinders, York: Joseph Rowntree Foundation.

Magadi, M. and Middleton, S. (2005), 'Britain's poorest children revisited: evidence from the BHPS (19942002)', CRSP Research Report 3, Loughborough University.

Preston, G. (ed.) (2005), At Greatest Risk: The Children Most Likely to be Poor, London: Child Poverty Action Group.

Sharma, N. (2007), It Doesn't Happen Here: The Reality of Child Poverty in the UK, Ilford: Barnardo's.

Strelitz, J. and Lister, R. (eds) (2008), Why Money Matters: Family Income, Poverty and Children's Lives, London: Save the Children.

Sutherland, H., Evans, M., Hancock, R., Hills, J. and Zantomio, F. (2008), The Impact of Benefit and Tax Uprating on Incomes and Poverty, York: Joseph Rowntree Foundation.

UNICEF (2005), 'Child poverty in rich countries, 2005', Innocenti Report Card 6, UNICEF Innocenti Research Centre, Florence.

UNICEF (2007), 'Child poverty in perspective: an overview of child well-being in rich countries', Innocenti Report Card 7, UNICEF Innocenti Research Centre, Florence, www.unicef-irc.org.

Work and Pensions Committee (2008), The Best Start in Life? Alleviating Deprivation, Improving Social Mobility and Eradicating Child Poverty, Second report of Session 2007-2008, Vol 1, HC 42-1, London: The Stationery Office. 